\title{
Immunofluorescence for routine diagnosis of respiratory syncytial virus infection
}

\author{
G. E. D. URQUHART ${ }^{1}$ AND G. H. WALKER \\ From the University of Glasgow Department of Infectious Diseases, Ruchill Hospital, Glasgow
}

SYNOPSIS A comparison of immunofluorescent tests for the diagnosis of respiratory syncytial (RS) virus infections was carried out on 42 hospitalized cases of respiratory infection in childhood. Respiratory syncytial virus was detected in $22(52 \%)$ cases, the most sensitive method of detection being by indirect immunofluorescence of Bristol HeLa tissue cultures inoculated with nasopharyngeal aspirates. The highest detection rate was in bronchiolitis cases $(92 \%)$. Detection of antibody rises in paired sera, eight days apart, confirmed RS virus infection in 13 of 16 cases, the most sensitive test being detection of a specific rise in IgG antibody by indirect immunofluorescence. A serodiagnosis was made in all 10 non-bronchiolitis cases. Recommendations are made for the application of immunofluorescence to routine diagnosis of RS virus infection.

The application of immunofluorescent techniques to diagnostic virology speeds up specific diagnosis for the clinician and improves laboratory efficiency by shortening specimen examination time. In order to determine the most efficient application of immunofluorescence to the diagnosis of respiratory syncytial (RS) virus infection in this area an evaluation of immunofluorescence tests was carried out directly on cells from nasopharyngeal aspirates and on inoculated tissue cultures. The application of immunofluorescence to diagnostic serology was also investigated.

\section{Materials and Methods}

Between November 1970 and February 1971 nasopharyngeal aspirates, throat swabs, and acute blood specimens were taken from infants with respiratory tract infection on admission to the Infectious Diseases Unit, Ruchill Hospital, Glasgow. Approximately eight days later second blood specimens were collected.

Nasopharyngeal aspirates were collected into plastic disposable mucus extractors using a suction machine and disposable plastic suction catheters (size no. 6). Four ml of viral transport medium was

'Present address: Virus Unit, Public Health Laboratory, Gloucestershire Royal Hospital, Southgate Street, Gloucester.

Received for publication 25 July 1972. sucked through the system to allow the mucoid aspirate to enter the mucus extractor. The material collected was centrifuged at $1000 \mathrm{rpm}$ for five minutes. At least four smears of cell deposit were examined by indirect immunofluorescence for RS virus antigen using reagents and methods previously evaluated and described (Urquhart and Martin, 1970). Supernatant fluids from nasopharyngeal aspirates and throat swabs were inoculated into two Bristol HeLa tissue culture tubes each and examined for RS virus antigen by indirect immunofluorescence after five to seven days' incubation.

Throat swabs were also examined for the presence of other respiratory viruses by inoculation into secondary monkey kidney and WI-38 tissue culture tubes.

Paired sera from infants from whom RS virus was isolated were examined for specific rise in antibody by immunofluorescence, complement-fixation, and neutralization tests. Three-day cultures of Bristol HeLa cells infected with $100 \mathrm{TCD}_{50}$ of a field strain of RS virus were used as antigen source for immunofluorescent antibody determinations. Conjugates from Burroughs Wellcome \& Co were used to determine specific antibody levels in $\operatorname{IgA}$, IgM, and IgG immunoglobulin classes. Neutralization tests using $100 \mathrm{TCD}_{50}$ of RS virus, complementfixation tests using eight antigen units, and other viral procedures were carried out as described by Grist, Ross, Bell, and Stott (1966). 


\section{Results}

Forty-two children were examined of whom 24 were male and 26 were under 6 months of age. Respiratory syncytial virus was detected in $22(52 \%)$ of the 42 cases. The clinical diagnoses and methods of virus detection are shown in Table I. By direct immunofluorescence of nasopharyngeal cells, $10(24 \%)$ cases were positive; RS virus was detected in tissue cultures inoculated with the supernatant from all of these specimens. Respiratory syncytial virus was detected in $21(50 \%)$ tissue cultures inoculated with nasopharyngeal aspirates but in only nine $(21 \%)$ of those inoculated with throat swabs.

The highest virus detection rate was in bronchiolitis $(92 \%)$ and three of these cases also yielded adenovirus (types 2 and 5); herpes simplex virus was isolated from one other case of RS-virus-positive bronchiolitis. Rhinoviruses were isolated from two RS-virus-negative cases with upper respiratory tract infection and pneumonia respectively, and herpes simplex strains were isolated from two cases of RS-virus-negative pneumonia.

Pairs of sera were available from 16 patients in whom RS virus was detected: the acute sera were collected a mean of four days after the onset of illness and second sera a mean of eight days later. The most efficient method for detection of a fourfold or greater antibody rise was immunofluorescence using antihuman IgG conjugate, and a polyvalent antihuman gamma globulin conjugate was almost as efficient in detecting specific IgG antibody rise (Table II). Progressively less sensitive were the neutralization test, detection of specific IgA antibody rise, complement-fixation test, and detection of specific IgM antibody rise. The mean IgG titres in the first and second sera were 10 and 160 respectively; the equivalent IgM titres were less than 10 and 40 . The other four serological tests gave intermediate mean titres. Antibody rises were detected in all 10 non-bronchiolitis cases but in only three of six bronchiolitis cases. This was not related to differences in age or time of sampling after the onset of illness.

\section{Discussion}

Although a diagnosis of RSvirus infection can be made in hours by immunofluorescent tests of aspirated nasopharyngeal cells, this method in our hands detected only half of the infections detected by indirect immunofluorescent examination of Bristol HeLa tissue cultures five to seven days after inoculation with the same specimens.

The main reason for the poor sensitivity of direct patient's cell immunofluorescence was the paucity of epithelial cells in smears and in some cases the possible masking of epithelial cells by large numbers of polymorphonuclear leucocytes. The separation of cell deposits from aspirated mucus was difficult Throat swabs taken at the same time also yielded only half the number of RS viruses detected from nasopharyngeal aspirates, confirming the increasedsensitivity of the latter specimens (Sturdy, McQuillin, and Gardner, 1969).

In agreement with Cradock-Watson, McQuillin,

\begin{tabular}{|c|c|c|c|c|c|}
\hline \multirow[t]{2}{*}{ Clinical Category } & \multirow{2}{*}{$\begin{array}{l}\text { No. in Each } \\
\text { Clinical } \\
\text { Category }\end{array}$} & \multirow{2}{*}{$\begin{array}{l}\text { No. }(\%) R S \\
\text { Viruses } \\
\text { Isolated }\end{array}$} & \multirow{2}{*}{$\begin{array}{l}\text { No. of Direct } \\
\text { Nasopharyngeal Cell } \\
\text { Smears FA positive }\end{array}$} & \multicolumn{2}{|c|}{ No. of Tissue Cultures FA Positive } \\
\hline & & & & $\begin{array}{l}\text { Nasopharyngeal } \\
\text { Aspirates }\end{array}$ & $\begin{array}{l}\text { Throat } \\
\text { Swabs }\end{array}$ \\
\hline $\begin{array}{l}\text { Upper respiratory tract infection } \\
\text { Bronchitis } \\
\text { Bronchiolitis } \\
\text { Pneumonia }\end{array}$ & $\begin{array}{r}11 \\
7 \\
12 \\
12\end{array}$ & $\begin{aligned} & 4(36) \\
& 5(71) \\
& 11(92) \\
& 2(17)\end{aligned}$ & $\begin{array}{l}3 \\
1 \\
4 \\
2\end{array}$ & $\begin{array}{r}4 \\
5 \\
10 \\
2\end{array}$ & $\begin{array}{l}2 \\
2 \\
5 \\
0\end{array}$ \\
\hline Total & 42 & $22(52)$ & 10 & 21 & 9 \\
\hline
\end{tabular}

Table I Detection of respiratory syncytial $(R S)$ virus by immunofluorescence $(F A)$

\begin{tabular}{|c|c|c|c|c|c|c|c|c|}
\hline \multirow[t]{2}{*}{ Clinical Category } & \multirow{2}{*}{$\begin{array}{l}\text { No. in Each } \\
\text { Clinical } \\
\text { Category }\end{array}$} & \multirow{2}{*}{$\begin{array}{l}\text { No. (\%) Showing } \\
\text { Antibody Rise }\end{array}$} & \multicolumn{6}{|c|}{ No. $(\%)$ Showing Antibody Rise by } \\
\hline & & & $\begin{array}{l}F A^{2} \\
(I g G)\end{array}$ & $\begin{array}{l}\text { FA (Anti- } \\
\text { human) }\end{array}$ & $\begin{array}{l}\text { Neutral- } \\
\text { ization }\end{array}$ & $\begin{array}{l}F A \\
(I g A)\end{array}$ & $\begin{array}{l}\text { Comple- } \\
\text { ment } \\
\text { Fixation }\end{array}$ & $\begin{array}{l}F A \\
(I g M)\end{array}$ \\
\hline $\begin{array}{l}\text { Upper respiratory tract infection } \\
\text { Bronchitis } \\
\text { Bronchiolitis } \\
\text { Pneumonia }\end{array}$ & $\begin{array}{l}5 \\
3 \\
6 \\
2\end{array}$ & $\begin{array}{ll}5 & (100) \\
3 & (100) \\
3 & (50) \\
2 & (100)\end{array}$ & $\begin{array}{l}5 \\
3 \\
2 \\
1\end{array}$ & $\begin{array}{l}4 \\
2 \\
1 \\
1\end{array}$ & $\begin{array}{l}4 \\
0^{3} \\
2 \\
2\end{array}$ & $\begin{array}{l}3 \\
0^{3} \\
1 \\
1\end{array}$ & $\begin{array}{l}2 \\
0^{3} \\
1^{3} \\
0\end{array}$ & $\begin{array}{l}1 \\
1^{3} \\
1 \\
0\end{array}$ \\
\hline Total & 16 & $13(81)$ & $11(69)$ & $8(50)$ & $8(53)$ & $5(33)$ & $3(21)$ & $3(20)$ \\
\hline
\end{tabular}

Table II Serological antibody rises in respiratory syncytial virus infections

${ }^{1}$ Fourfold or greater increase ; ${ }^{2}$ Immunofluorescence; ${ }^{3}$ One case not tested. 
and Gardner (1971) the isolation rate was high (92\%) in bronchiolitis cases and lower in other clinical categories of respiratory infection $(17 \%$ to $71 \%)$.

Detection of antibody rises in paired sera approximately eight days apart allowed a confirmatory diagnosis to be made in all 10 non-bronchiolitis cases and three of six cases of bronchiolitis, the most sensitive test being the detection of specific IgG antibody rise by immunofluorescence. Advantages of this sensitive test are that it requires only small amounts of serum and can detect antibody rises within eight days of admission when the infants are still in hospital. Tests can be carried out quickly if suitable stored slides of RS virus-infected cells are available.

Unless specific or selective therapy is available for cases of serious RS virus infection rapid diagnosis is not essential. For efficient routine diagnosis of RS virus infection we consider the method of choice for bronchiolitis cases to be by immunofluorescent tests of Bristol HeLa tissue cultures inoculated with nasopharyngeal aspirates at five to seven days' incubation, and in non-bronchiolitis cases by detection of antibody rise in sera, eight days apart, by immunofluorescence for specific IgG antibody.

\section{References}

Cradock-Watson, J. E., McQuillin, J., and Gardner, P. S. (1971). Rapid diagnosis of respiratory syncytial virus infection in children by the immunofluorescent technique. J. clin. Path., 24, 308-312.

Grist, N. R., Ross, C. A. C., Bell, E. J., and Stott, E. J. (1966). Diagnostic Methods in Clinical Virology. Blackwell, Oxford.

Sturdy, P. M., McQuillin, J., and Gardner, P. S. (1969). A comparative study of methods for the diagnosis of respiratory virus infections in childhood. J. Hyg. (Lond.), 67, 659-670.

Urquhart, G. E. D. and Martin, K. W. (1970). Respiratory syncytial virus tissue culture immunofluorescence as a laboratory aid. Arch. ges. Virusforsch., 32, 365-372. 